\title{
Macro Variable Effect Analysis and Non- Performing Financing (NPF) Against the Return on Asset (ROA) Islamic Banks in Indonesia Year 2008-
} 2017

\author{
Dwi Pratika Karisma', Fikri 'Ainul Qolbi', and Imron \\ Rosyadi $^{3}$ \\ ${ }^{1}$ Faculty of Islamic Studies, University of Muhammadiyah \\ Surakarta \\ email: pratikadwikarisma3@gmail.com \\ ${ }^{2}$ Faculty of Islamic Studies, University of Muhammadiyah \\ Surakarta \\ email: fikriqolbi@gmail.com \\ ${ }^{3}$ Faculty of Islamic Studies, University of Muhammadiyah \\ Surakarta \\ email: ir120@ums.ac.id
}

\begin{abstract}
Islamic Banks is a business entity that raises and distributes funds from the community and for the community. The study was conducted to analyze the macro variables and NPF (NonPerforming Finance) to ROA (Return on Assets) to determine the relationship between short-term and long-term between variables. The analysis model used is the Engle Granger ECM Stage Two test that uses secondary data from the serial data (time series). The results of this study indicate that NPF simultaneously, GDP, and interest rates affect the ROA. Partially GDP positive and significant effects in the long term and short term, NPF positive and significant effect in the long term, interest rate, and no significant positive effect on ROA.
\end{abstract}

Keywords: ROA, Islamic Banks, NPF, GDP, Two-Stage ECM Engle Granger 


\section{INTRODUCTION}

Banking stability is essential for the prevailing economic situation of a country. At the time of the 1997 economic crisis and the 2008 global economic crisis, which negatively impacts the stability of the financial system, this confirms the stability of the banking affects the state of the economy. (Dimas, 2018)

Today, the Islamic Banks are banks that operate profitoriented, then in its operations fixed for profit or gain. Rate to performance of a bank can be done by analyzing the financial statements of the bank, particularly the ratio calculation in order to evaluate the financial situation in the past, present, and future. The ability of a company to generate profits or earnings usually referred to profitability, where Islamic Banks must demonstrate its ability to generate profits obtained through customer deposit and fundraising.

In each study, the preparation of the development of statistical data that contains information about the real condition of profitability in Islamic Banks is needed to determine the development Return on Assets (ROA) of Islamic Banks, the development of an increasing or decreasing the current quarter in each year is different (Nenda, 2016). This definition describes the goals that will be investigated is the company's profit and use the Return on Assets (ROA) Islamic Banks in Indonesia in 2008 - 2017. The following is a table Return on Assets (ROA) Islamic Banks in 2008 -2017.

Table 1. ROA development of Islamic Banks

in Indonesia in 2008 - 2017

\begin{tabular}{ccccc}
\hline Year & TW 1 & TW 2 & TW 3 & TW 4 \\
\hline 2008 & 1.83 & 1.81 & 1.84 & $1: 57$ \\
2009 & $2: 44$ & $2: 16$ & $1: 38$ & $1: 48$ \\
2010 & 2.1 & 1.66 & 1.77 & 1.67 \\
2011 & 1.97 & 1.84 & 1.8 & 1.79 \\
2012 & 1.83 & $2: 05$ & $2: 07$ & $2: 14$ \\
2013 & $1: 39$ & 2.1 & $2: 04$ & 2 \\
2014 & $1: 16$ & $1: 12$ & 0.97 & 0.8 \\
2015 & 1.69 & 0.5 & $0: 49$ & $0: 49$ \\
\hline
\end{tabular}




\begin{tabular}{ccccc}
\hline Year & TW 1 & TW 2 & TW 3 & TW 4 \\
\hline 2016 & 0.88 & 0.73 & $0: 59$ & 0.63 \\
\hline 2017 & $1: 12$ & 1.1 & 1 & 0.63 \\
\hline
\end{tabular}

Source: FSA, the data is processed

In Table 1.1, it can be seen that the ROA was progressing volatile. In 2008 - 2017 first quarter, the highest number of ROA in 2013 amounting to $2.39 \%$ ROA considered very healthy this year due. While the lowest ROA in 2008 - 2017 first quarter occurred in 2015 at $0,69 \%$ in the category of pretty healthy. Then, in the second quarter, the number of the highest ROA in 2009, which amounted to $2,16 \%$ are categorized ROA very healthy this year. While the lowest ROA second quarter occurred in 2015 at $0.5 \%$ categorized as healthy enough. Then, the third quarter of the amount of the highest ROA in 2009, which amounted to $2.04 \%$ ROA considered very healthily this year. While the lowest ROA third quarter occurred in 2015 amounted to $0.49 \%$ less healthy. After categorized it, ROA fourth quarter the highest number in 2009 , which amounted to $2.00 \%$ ROA considered very healthily this year. While the lowest ROA fourth quarter occurred in 2015 amounted to $0.49 \%$ categorized as less healthy.

Non-Performing Financing (NPF) or often referred to as non-performing loans, can be defined as the ratio to determine problems financing borne by the bank based on the total finance portfolio in order to measure the level of financing issues faced by the bank (Rahman, Asaduzzaman, \& Hossin, 2017). The higher this ratio, indicating the quality of bank financing to get worse. Here are presented in Table NPF development of Islamic Banks in 2008-2017.

Table 2. The development of NPF ((Net Performing Financing) Islamic Banks in Indonesia in 2008 - 2017

\begin{tabular}{ccccc}
\hline Year & TW 1 & TW 2 & TW 3 & TW 4 \\
\hline 2008 & $4: 17$ & $4: 23$ & $4: 12$ & 3.95 \\
2009 & $5: 14$ & $4: 39$ & 5.72 & $4: 01$ \\
2010 & $4: 53$ & 3.89 & 3.95 & $3: 02$ \\
2011 & 3.6 & 3.76 & 3.5 & $2: 52$ \\
2012 & 2.76 & 2.88 & 2.74 & $2: 22$ \\
\hline
\end{tabular}




\begin{tabular}{ccccc}
\hline Year & TW 1 & TW 2 & TW 3 & TW 4 \\
\hline 2013 & 2.75 & 2.64 & 2.8 & 2.62 \\
2014 & $3: 22$ & 3.9 & $4: 57$ & $4: 33$ \\
2015 & $5: 49$ & $5: 09$ & $5: 14$ & 4.74 \\
2016 & $5: 35$ & 5.68 & $4: 57$ & $4: 42$ \\
2017 & $4: 51$ & $4: 47$ & $4: 41$ & 4.67 \\
\hline
\end{tabular}

Source: FSA, the data is processed

In Table 1.2, it can be seen that the average - average NPF relief the second quarter of 2016 is as high as $5.68 \%$, while the lowest NPF in 2008 to 2017 occurred in the fourth quarter of 2012 is relatively low at $2.22 \%$. More detail is the highest first quarter in 2015 is 5.49\%, and the lowest in 2012 amounted to $2.75 \%$, the highest. Quarterly II in 2016 is $5.68 \%$, and the lowest in 2013 amounted to $2.64 \%$. Quarterly highest III in 2009 is $5.72 \%$, and the lowest in 2012 amounted to $2.74 \%$. Quarterly highest IV in 2015 is $4.84 \%$, and the lowest in 2012 amounted to $2.22 \%$.

In the context of the macroeconomy, the widespread use of a variety of products and financial instruments sharia addition to support the financial and business community also reduces the transactions that are speculative thus supporting the overall financial stability, which in time will provide a significant contribution to the achievement of price stability mid-term up with the long-term (Syachfuddin, 2017).

Macro variables that will be tested its effect on Return on Assets (ROA) Islamic Banks are the BI rate, and the Gross Domestic Product (GDP).

This study aimed to determine the effect of macro variables on Return On Assets (ROA), and Net Performing Financing (NPF) on Return On Assets (ROA) of Islamic banks, as well as determine the relationship Short Term and Long Term through cointegration among the variables of writing,

This paper is expected to have benefits as a reference for future writing as well as fill material for the institutions involved in policy-making related to the influence of macro variables and Net Performing Financing (NPF) on the Return on Assets (ROA) Islamic Banks. 


\section{LITERATURE REVIEW \\ Understanding Islamic Banks}

Islamic banks are part of islamic banking, by-law no. 21, 2008, article 1, paragraph 1 states "islamic banking is everything related to the islamic banks and islamic business unit, covering institutional, business activities, as well as the manner and process of carrying out its business activities.'(Undang-Undang, 2008).

Special definition Islamic Bank under the Law 21, 2008, article 1, paragraph 7 that "Islamic Banks and by type consisting of Islamic Banks and Sharia Bank Financing People." Meanwhile, Sharia Bank principles stated in Law No. 21, 2008, article 1, paragraph 12 "Sharia is Islamic law principles in banking activities based on a fatwa proposed by the agency that has the authority in setting the fatwa in the field of sharia."

Islamic Banking has a different goal with conventional banking, where Islamic Banking objectives contained in Law No. 21, 2008, article 3, namely, "Islamic Banking aims to support the implementation of national development in order to improve the fairness of togetherness, and equalization of the people Welfare services."

Islamic Banking functions outlined in Law No. 21, 2008, article 4, among others, shall perform the functions of collecting and distributing public funds, running a social function in the form of institutions treasury, which receives funds from the charity, donation, charity, hibah or other social funds and channel them to the organization of zakat, collect social funds derived from endowments money and distribute it to the management of waqf (nazir) something with the will of the giver waqf (wakif), and the implementation of social functions referred to paragraphs 2 and 3 correct with the provisions of the legislation.

\section{Profitability ratios}

Profitability shows the company's ability to generate income for a particular year. In the world of banking, income can be obtained from lending. Each lending to customers, the customer must repay the loan following the agreement between the customer and the bank. 
The higher the loans be greater oversight of the loans so that no non-performing loans, due to non-performing loans will lead to a decrease in revenue for banks, due to customers are not able to repay the loan that had been loaned.

\section{The Benefits of Profitability}

Profitability has benefits that are very important and can be used as an analysis of the ability to generate profits shown to detect the cause of the profit or loss generated by object information in the accounting year, describing criteria indispensable in assessing the success of a company data terms of capability and motivation of management. Profitability is a tool to make the company profit forecast because it describes the correlation between income and the amount of capital invested.

ROA is the ratio used to determine the ability of the bank's management in the overall profit and the bank rate, which is better than the other bank profitability ratios. The greater the ROA in getting, the greater the profits obtained and the better position of the bank in terms of asset utilization. The evaluation criteria for the soundness ratios Return on Assets (ROA) can be seen in Table 3 as follows:

Table 3. Assessment criteria

Health Level Ratios ROA

\begin{tabular}{cc}
\hline ratios & Predicate \\
\hline $\mathrm{ROA}>1.5 \%$ & Very healthy \\
$1.25 \%<\mathrm{ROA} \leq 1.5 \%$ & Healthy \\
$0.5 \%<\mathrm{ROA} \leq 1.25 \%$ & Fit \\
$0 \%<\mathrm{ROA} \leq 0.5 \%$ & Unwell \\
$\mathrm{ROA} \leq 0 \%$ & Not healthy \\
\hline
\end{tabular}

Source: Bank Indonesia

\section{Definition of Net Performing Financing (NPF)}

The ratio is used to determine the financing problems incurred by the bank based on the total financing disbursed (Indah, 2016). Based on Bank Indonesia regulation through Bank Indonesia 
Circular Letter No. 9/29 / DBPs dated December 2007. NPF can be calculated using the formula:

\section{Net Interest Performing Financing (NPF)}

To measure the level of financing problems faced by the bank. The higher this ratio, indicating the quality of financing of Islamic banks, is getting worse. In Table 2.1 explains the criteria for the rating of the NPF ratio.

Table 4. Assessment criteria NPF ratio Soundness

\begin{tabular}{cc}
\hline criterion Research & Ranked \\
\hline $\mathrm{NPF}<2 \%$ & Very healthy \\
$2 \% \leq \mathrm{NPF}<5 \%$ & Healthy \\
$5 \% \leq \mathrm{NPF}<8 \%$ & Fit \\
$8 \% \leq \mathrm{NPF}<12 \%$ & Unwell \\
$\mathrm{NPF} \geq 12 \%$ & Not healthy \\
\hline
\end{tabular}

Source: Bank Indonesia

\section{Gross Domestic Product (GDP)}

Gross Domestic Product (GDP) is one important indicator to determine the economic development in a country in a given year, both based on current prices and based on constant prices (Cupian, 2016). GDP is the amount of added value generated by all business units in a particular country in a given year. The total value of final goods and services provided from production must be the same as the value of the goods used.

Keynes's theory states that saving in a country is influenced by the amount of income received by society rather than influenced by the interest rate.

Economic growth is the development of activities in the economy that causes the goods and services produced in society to increase as well. The data used to measure a country's economic growth is to calculate real national income or GDP (Gross Domestic Product) according to constant prices (prices that apply in the base year) that are applied from year to year (Rehmat, 2012). 
Increased income of the community resulted in increased consumption and savings of the community so that when there is economic growth marked by an increase in people's income, banking profitability can increase because of the savings that encourage banks to increase the allocation of funds through credit.

\section{Definition of Interest Rates}

The BI interest rate is the interest rate policy of Bank Indonesia, which is a reference for interest rates on the money market. Changes in BI interest rates are followed by changes in deposit rates and lending rates with directional (positive) movement. Interest rates are divided into two types, as follows:

1. The nominal interest rate (also known as usury) is the interest rate on money in terms of money.

2. Real interest rates, corrected for inflation and calculated as nominal interest rates minus inflation.

\section{Previous Research}

Setiawati (2016) analyzed the "Macro Variable Effect on Profitability Islamic Bank." This study aimed to analyze the influence of macro variables on the profitability of Islamic banks in Indonesia during the period 2004 - 2014, the method used in this research is time series by using multiple linear regression analysis models. The results showed that inflation and currency exchange rates did not affect the profitability of Islamic banks, the gross domestic product (GDP) significantly with positive direction towards the profitability of Islamic banks, and interest rates have a significant effect in the negative direction towards the profitability of Islamic banks.

Kuncoro (2018) analyzed the "Impact of Macroeconomy an indicator of the profitability of Islamic Banking in Indonesia during the period 2013-2017'. This study aims to determine the effect of variable inflation, BI, Capital Adequacy (CAR) and the Gross Domestic Product on the profitability of Islamic banks in the premises the period 2013-2017 demonstrated through the Return On Asset (ROA), the method of selecting the sample used is the convention sampling, Model analysis using panel 
data regression analysis. The results showed that the variables of inflation, interest rates BI, CAR, GDP together affect ROA. In the partial test variable inflation and CAR does not influence ROA. Interest rates and GDP have a significant influence in the opposite direction.

Sari (2014) analyzed the "Analysis of the influence of variable Non-Performing Financing (NPF), Financing To Deposit (FDR), and the Capital Adequacy Ratio (CAR) on the level of profitability in Islamic Banks." This study aimed to examine the effect of variable Non-Performing Financing (NPF), Financing To Deposit (FDR) and the Capital Adequacy Ratio (CAR) of the Return On Asset (ROA) as a proxy for the profitability of Islamic banks in the premises the period 2009-2013, the research data the use of secondary data and data analysis method used is multiple linear regression analysis. The results of this study indicate that the variable Non-Performing Financing (NPF), Financing To Deposit (FDR), and the Capital Adequacy Ratio (CAR) jointly affect the return on assets (ROA). Partially, NPF variable positive and significant impact on ROA, FDR variable, and no significant positive effect on ROA. Meanwhile, CAR and no significant adverse effect on ROA. The third prediction available ability to ROA $22.7 \%$ While rest influenced by other factors outside of this study.

\section{METHODS}

The method used in this research is using quantitative research methods. As for the model analysis in this study using dynamic linear regression analysis. Data processing equipment used in the research is computer software in Eviews8 with Stage Two analytical models ECM Engle Granger. The relationship has a functional relationship with the following formula:

Long-term equation model:

$R O A_{t}^{*}=\beta O+\beta_{1} N P F_{t}+\beta_{2} P D B_{t}+\beta_{3} R_{t}+u_{t}$

Where,

ROA : Return On Asset 


$\begin{array}{ll}\beta 0 & : \text { Constants } \\ \text { NPF } & : \text { Net Performing Financing } \\ \text { PDB } & : \text { Gross domestic product } \\ \text { R } & : \text { The interest rate } \\ \beta 1, \beta 2, \beta 3 & : \text { Parameter } \\ \text { Ut } & : \text { Error correction term }\end{array}$

Short Term Equation Model:

$\Delta R O A_{t}=\gamma o+\gamma_{1} \Delta N P F_{t}+\gamma_{2} \Delta \log (P D B)_{t}+\gamma_{3} \Delta R_{t}+\gamma_{4} E C T+u_{t}$

Where,

ECT : Resid01 (-1)

${ }_{\gamma} 1 \quad: \mathrm{A} 1 ; \gamma 2=\alpha 2 ; \gamma 3=\alpha 3$, short-term coefficients

y0 $\quad \lambda \beta \mathrm{o}$

y4 $\quad \lambda$; adjustment coefficient

\section{RESULTS AND DISCUSSION}

\section{Results Estimates}

The estimation results Error Correction Model (ECM) above are presented in table 5

Table 5. ECM Model Estimation Results

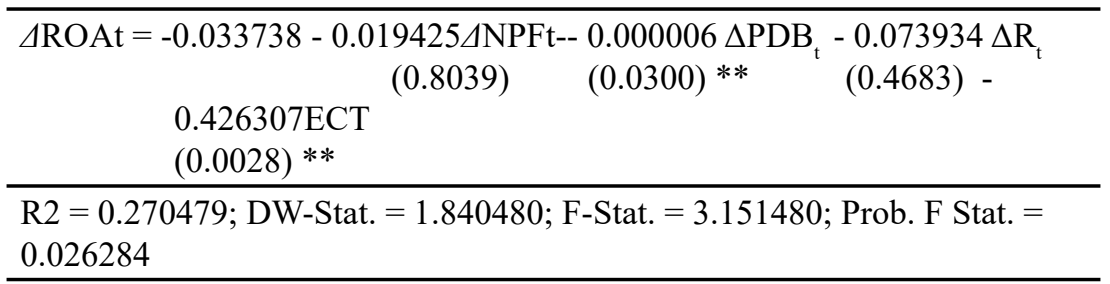

Source: Indonesian Banking Statistic, processed. Notes: * Significant at $\alpha=$ $0.01 ; * *$ Significant at $\alpha=0.05 ; * * *$ Signifikasni at $\alpha=0.10$. Figures in brackets are the t-statistic probability value.

Table 5 Regression coefficients based ECT ((Resid01 (-1)) qualify ECT coefficient should be negative (-) of - 0.426307 . This coefficient or probability p-value (significance) empirical $t$ statistics coefficient of 0.0028 , which means a significant ECT on $\alpha=(0.05)$. This shows that the model is a model tersetimasiTwo 
Stage ECM Engle Granger, where there is a long-term relationship between the variables Dependent and independent variables in the econometric model in this study

\section{Goodness Test Model}

\section{Existence Model (test F)}

In a test of the $\mathrm{F}$, the model is said to exist when all independent variables simultaneously or together influence the dependent variable. Instead, the model is said not to exist when all independent variables simultaneously or with no effect on the dependent variable, with sig criteria. $\mathrm{F}<\alpha$ (where $\alpha=0.05$ ), then the model exists and if sig. F> $\alpha$, otherwise the model does not exist. Based on Table 4.6, it can be seen the value of statistical probability or empirical estimation model has $\mathrm{F}$ on the value 0.026284 , which means that $0.026284>0.05$, the conclusion of the model used in the research exists.

\section{Interpretation of the Coefficient of Determination}

The coefficient of determination (R2) shows the power of prediction of the model digress. Based on Table 4.6, it can be seen as an R2 value of 0.270479 or $27 \%$. The variation of the dependent variable ROA (Return on Assets) can be explained by the independent variable NPF (Non-performing Finance), GDP (Gross Domestic Product), and R (Interest Rates). Meanwhile, the rest of the $73 \%$ is explained by other variables outside the model.

\section{Test Validity Effect (t-test)}

Test Validity Effect (t-test) was conducted to determine the effect of the independent variable on the dependent variable partially or not together. Validity test results for the influence of all independent variables in the model of the Long-Term and Short-Term Model is presented in Table 6 
Table 6. The validity of Test Results Independent Variables Influence

\begin{tabular}{ccccc}
\hline \multicolumn{2}{c}{ variables } & Sig. T & Criteria & Conclusion \\
\hline \multirow{2}{*}{$\begin{array}{c}\text { Longterm } \\
\text { model }\end{array}$} & NPF & 0.0009 & $<0: 05$ & significant at $\alpha=0: 05$ \\
& PDB & 0.0011 & $<0: 05$ & significant at $\alpha=0: 05$ \\
\multirow{2}{*}{ Shortterm } & D (NPF) & 0.8039 & $>0.05$ & not significant \\
model & D (GDP) & 0.0300 & $<0: 05$ & not significant \\
& D (R) & 0.4683 & $>0.05$ & not significant \\
\hline
\end{tabular}

Source: organized data

\section{Interpretation of Independent Variables Influence}

Based on Table 6, it can be seen that the independent variables have a significant effect in the long term is the NPF (Net Performing Finance) and GDP (Gross Domestic Product). In contrast, the independent variables that have a short-term effect are the GDP (Gross Domestic Product).

Variable NPF (Net Performing Finance) has a coefficient regression of 0.0009 . The pattern of the relationship between the independent variables NPF (Net Performing Finance) and variable dependent ROA (Return on Assets) is a linear-linear then when the NPF (Net Performing Finance) rose one percent, the ROA (Return on Assets) will rise -0.279377 percent. Conversely, if the NPF (Net Performing Finance) fell one percent, the ROA (Return on Assets) will go down -0.279377.

Variable GDP (Gross Domestic Product) in the longterm model regression coefficient of 0.0011 , the pattern of the relationship between variable, independent GDP (Gross Domestic Product) and variable dependent ROA (Return on Assets) is a linear-linear then when and variable dependent ROA (Return On Assets ) is a linear-linear then when the GDP (Gross Domestic Product) rose one billion then ROA (return on assets) will rise -0.0000011 percent. Conversely, if the GDP (Gross Domestic Product) fell one billion, then ROA (Return on Assets) will go down -0.0000011 .

Variable GDP (Gross Domestic Product) in the model of short-term regression coefficient of 0.0300 , the pattern of the relationship between the independent variables GDP (Gross 
Domestic Product) and ROA (Return on Assets) is a linear-linear then when the GDP (Gross Domestic Product) rose one billion the ROA (Return on Assets) will rise -0.0000014 percent. Conversely, if the GDP (Gross Domestic Product) fell one billion, then ROA (Return on Assets) will go down - 0.0000014 .

\section{Economic Interpretation}

The data in this study describes the effect of long-term model and a model of short-term macro variables such as GDP, interest rate (R) and non-performing Finance (NPF) on Return On Assets (ROA) Islamic Banks in Indonesia, where the long-term model independent variables Non-Performing Finance (NPF) and the independent variables GDP effect on Return on Assets (ROA). Meanwhile, in the short-term model of independent variables that influence. Variable GDP-a significant independent variable on the dependent variable can be intrepeted as follows:

\section{Gross Domestic Product (GDP) and Return on Assets (ROA)}

Based on estimates of data, gross domestic product, and a significant positive effect on Return On Assets (ROA) Islamic Banks in Indonesia. Gross Domestic Product in the model of longterm and short-term model has a negative effect, but significant on Return On Assets (ROA). Gross Domestic Product is aimed to determine the development of economic growth in a country in a given period. The economic development of a country as well should influence banking profitability in the country, the growing economy of a country may indicate that people in a state of peace with incomes afford their tubes for investment and productivity using funds from the Bank. The results are consistent with research conducted by research Setiawati (2016) in which the gross domestic product (GDP) significantly with positive direction towards the profitability of Islamic banks. The results are also consistent with studies Kuncoro (2018) GDP has a significant influence in the opposite direction. 


\section{Non-Performing Finance (NPF) and Return on Assets (ROA).}

Based on estimates, data show that in the long-term model of non-performing Finance (NPF), but the significant negative effect on Return On Assets (ROA) Islamic Banks in the Indonesia quarter of the year 2008-2017. Non-Performing Finance (NPF) is a ratio used to determine the financing problems in a bank, in the period from year 2008 to 2017 the development of nonperforming Finance (NPF) can be said to be concerned about this because the refund of credit due to financing problems or inhibit the growth of bad loans banking itself.

Results of the study, according to the study Sari (2014) NPF variable positive and significant impact on ROA. However, the results in this study are not consistent with studies Saputra (2015), where the research financing problems as measured by non-performing Finance (NPF) will not lead to profitability or return on assets (ROA) increased or decreased.

\section{CONCLUSION}

Based on the results of the analysis of the influence of macro variables (Gross Domestic Product (GDP), interest rates and non-performing financing (NPF) on Return On Assets (ROA) Islamic Banks in Indonesia in 2008-2017 can be concluded as All independent variables namely Non-performing financing (NPF), Gross Domestic Product (GDP), and interest rates simultaneously or together affect the Return On Asset (ROA) Islamic Banks in Indonesia amounted to $27.04 \%$. Another finding is under the influence of the validity of the test ( $t$ test), partially independent variable interest rates did not have a significant effect in the short-term model of 0.4683 and 0.6110 for the long-term model. Meanwhile, the independent variable of non performing financing (NPF) significantly in the long-term model of 0.0009 and the short-term model is not significant at 0.8039 , and for the gdp variable has a significant influence both in the short-term model of 0.0300 and 0.0011 for the long-term model. The research suggests the influence of macro variables, as external variables that gross domestic product (GDP) and central bank interest 
rate on return on assets (ROA) and internal variables ie nonperforming financing (NPF) on return on assets (ROA). Together or simultaneous external variables and internal variables affect the return on asset (ROA) it can be interpreted that external variables and internal variables in the short term and long term effect on the return on assets (ROA), partial variable interest rates have a significant effect in the short term and long term, a significant effect dalamjangak npf variable short and insignificant in the long term and gdp variables have a significant effect in both the short and long term.

\section{REFERENCES}

Cupian, A. (2016). "The Impact Macroeconomic Variables on Indonesia Islamic Banks Profitability." Jurnal Ekonomi Dan Bisnis Islam, Vol. 02.

Dimas, B. W. K. (2018). Analysis of the impact on selected macroeconomic Indicators on Islamic Banks Profitability Indonesia. International Journal of Economics Business and Management Research (IJEBMR), Vol. 02(Issue. 04).

Indah, D. P. (2016). Pengaruh Non Performing Loan and Capital Adequancy Ratio (CAR) terhadap Propabilitas. Jurnal Managemen Fakultas Ekonomi. Universitas Negeri Semarang.

Kuncoro, G. T. (2018). Dampak indikator Makro terhadap Profitabilitas perbankan Syariah. Universitas Muhammadiyah Surakarta.

Nenda, N. N. (2016). Pengaruh CAR, Pembiayaan, NP dan BOPO terhadap ROA Bank Umum Syariah. Universitas Diponegoro.

Rahman, M., Asaduzzaman, M., \& Hossin, M. (2017). Impact of Financial Rations on Non-performing Financings of Publicly Traded Commercial Banks in Bangladesh. International Journal of Financial Research (IJFR), Vol. 08(Issue. 01).

Rehmat, U. A. (2012). Foreign Direct Investment, Economic Growth, Trade, and Domestic Investment Relationship : An 
Econometric Analysis of Selected South Asian Countries. Interdisciplinary Journal Of Contemporary Research In Business (IJCRB), Vol. 03(Issue. 09).

Saputra, T. A. (2015). Pengaruh Variabel Makroekonomi terhadap ProfitabilitasPerbankan Syariah di Indonesia periode 2010-2013. Universitas Muhammadiyah Surakarta.

Sari, A. W. (2014). Analisis pengaruh Variabel Non Performing Financing (NPF), Financing To Deposit (FDR) dan Capital Adequacy Ratio (CAR) terhadap Tingkat Profitabilitas pada Bank Umum Syariah. Jurnal Kajian Ilmiah Akuntansi Fakultas Ekonomi, Vol. 3.

Setiawati, M. L. (2016). Pengaruh Variabel Ekonomi makro terhadap profitabilitas Bank Syariah. Jurnal Ekonomi Manajemen.

Syachfuddin, D. (2017). Pengaruh Faktor Makroekonomi, Dana Pihak ketiga, dan Pangsa Pembiayaan terhadap profitabilitas Industri perbankan Syariah di indonesia tahun 2011- - 2015. Jurnal Ekonomi Syariah Teori Dan Terapan, Vol. 4.

Undang-Undang. UU No. 21 tahun 2008 tentang Perbankan Syariah., (2008). 